\title{
Impact Study on Manual Paddy Transplanters in Trichy District
}

\author{
G. Anand ${ }^{1}$ and G. Amuthaselvi ${ }^{2 *}$ \\ ${ }^{1} H C \& R I(W), T N A U$, Trichy-9, India \\ ${ }^{2} A E C \&$ RI, TNAU, Coimbatore, India \\ *Corresponding author
}

\section{A B S T R A C T}

\section{Keywords}

Rice, Transplanters and Drudgery

Article Info

Accepted:

20 January 2021

Available Online:

10 February 2021
Transplanting of rice is either done manually or by machines. Transplanting of wash root seedlings of rice by hand is most common practice among Indian farmers. This method required higher manual labor and more time as compared to mechanical transplanting. Trichy district was selected to study the impact of mechanical transplantation and the district is falling under Cauvery delta Zone. The interview schedule for farmers (beneficiaries) survey covered aspects such as general farm and household characteristics, details on cultivation practices adopted in Rice cultivation, cost details of cultivation, merits and demerits of the mechanical transplanting. Majority of the beneficiaries farming experience ranged between 21 and 30 years. Beneficiaries were distributed in the descending order of medium, small and marginal farmer categories. Around 90 per cent of the beneficiaries were in the annual income around Rs. 1 lakh. Beneficiaries reported the significantly reduced the mental agony in rice cultivation, increased the number of productive tiller, reduced seed rate resulted in reduction of cost of cultivation.

\section{Introduction}

Rice is one of the most important crop and staple food of millions of people which is grown in many countries of the world. The total area planted under rice crop in India is 42.20 million ha, which is the largest in the world as against the total area of 148.40 million ha (Tripathi et al., 2004). Paddy is largely grown traditionally by manual transplanting. Manual transplanting requires a lot of labours besides involving drudgery and is also very expensive. Scarcity of labours is another major problem in some paddy growing area of the country. Manual transplanting takes about 250-300 man hours/ha which is roughly about 25 per cent of the total labour requirement of the crop. Hence, less expensive, farmer friendly and labour saving method of paddy transplanting is urgently needed. The mechanical transplanting of paddy has been considered the most promising option, as it saves labour, ensures timely transplanting and attains optimum plant density that contributes to high productivity. Keeping this in view, the study was conducted on impact of paddy transplanter to minimize the cost of transplanting of paddy crop through farm mechanization. 


\section{Materials and Methods}

\section{Study area}

Rice is one of the predominant crops grown in Tamil Nadu particularly in the Trichy, district. Trichy district was selected to study the impact of mechanical transplantation and the district is falling under Cauvery delta Zone. Based on the number beneficiaries of the program in district, proportionate random sampling procedure was followed to select sample respondents.

\section{Sampling design}

The details of sample villages and number of paddy growing farmers selected in the study area are given in Table 1.

To understand the impact of the mechanical transplanting among the rice growers primary data were collected from the 250 sample farmers distributed in the Trichy district of Cauvery delta.

\section{Period of the study}

The primary data were collected from the sample respondents and the data collected with regard to mechanical transplanting of Rice pertain to the Kuruvai.

\section{Primary data}

A well structured interview schedule was used to collect primary data. The questionnaires were pre-tested and finalized. The interview schedule for farmers (beneficiaries) survey covered aspects such as general farm and household characteristics, details on cultivation practices adopted in Rice cultivation, cost details of cultivation, merits and demerits of the mechanical transplanting.
Size of land holding of the farmers may influence the cropping pattern, farm mechanization and buying behavior of the farmers with respect to agricultural inputs. Annual income of the family is directly related to the risk taking ability, adoption of new technologies and investment opportunities in the farm venture. Annual income of the sample farmers were divided into 3 categories less than 1 lakh, 1-2 lakh and more than 2 lakh. A well structured interview schedule was used to collect primary data. The questionnaires were pre-tested and finalized. The interview schedule covered the aspects such as farmers' personal particulars, Kuruvai land use pattern, crop cultivation details with special reference to cost factor in both conventional and machine planting methods, merits and demerits of the mechanical transplanting.

\section{Results and Discussion}

In Trichy district, Musuri and Lalgudi are the two delta blocks Tamil Nadu has implemented the Kuruvai Package. Based on the number beneficiaries of the program in each districts, proportionate random sampling procedure was followed to select sample respondents. It has been decided to select 25 per cent of the population as sample, and accordingly the sample size has been fixed by adopting proportionate random sampling method. As the study focuses on the impact of the machine transplantation, As the study focuses on the impact of the machine transplantation, Among the selected farmers, some of them were practiced the convention and some were adopted mechanical transplanting. These control farmers were selected considering their rich experience in Kuruvai cultivation. The above methodologies were prepared for cost factor in both conventional and machine planting methods, merits and demerits of the mechanical transplanting (Table 2). 


\section{Data analysis}

Finally the data collected were tabulated in excel master sheet. Sub tables were prepared from the master table and percentage analysis was carried out to get meaningful interpretation of the results.

\section{Comparative economics in seedling production per acre}

The comparative economics of seedling production per acre is given in Table 3 . In this part of analysis three situations of seedling production were taken for working out the economics of seedlings namely convention method of seedling production for conventional planting (traditional method), mat nursery method of seedling production for mechanical transplanting by farmers themselves and third one is out write purchase of seedlings from nurseries owned by agripreneurs.

It could be seen from the table 3 that yield (productivity) increase of more than 20 per cent was report in case of mechanically transplanted fields as compared to the conventional planted fields. Cost of cultivation was almost 13 per cent lesser in case of mechanically transplanted fields as compare to conventional planted fields, this mainly due to reduction in seed cost (reduction in quantity of seeds), reduction in manures and fertilizer application and plant protection. Because of reduction or saving in the cost of cultivation automatically resulted in fall in cost of production. Finally, it was very well demonstrated and reported by the study farmers that gross return and net return were significantly higher (10 per cent increase in gross return and increased 1.5 times (65.8 percentage) in net return). This mainly because of more tiller per hill was report almost all the farmers who have adopted the mechanical transplanting. Farmers reported that almost 30 to 40 per cent increase in number of tillers per hill. This would increase the over increase in the yield / productivity of the crop. Transplanting gave significantly higher paddy yield as compared to different direct sowing methods (Ehsanullah, et al., 2000).

Table.1 Distribution of Sample Farmers in Trichy District (in Numbers)

\begin{tabular}{|c|c|c|c|}
\hline S. No. & District & $\begin{array}{c}\text { Total number of } \\
\text { beneficiaries }\end{array}$ & Number of sample farmers \\
\hline 1. & Trichy & 44 & 11 \\
\hline
\end{tabular}

Table.2 Primary data of sample farmers

\begin{tabular}{|c|c|c|c|c|}
\hline S.No. & $\begin{array}{c}\text { Age } \\
\text { (years) }\end{array}$ & Education & $\begin{array}{c}\text { Size of Land } \\
\text { holding (in ha) }\end{array}$ & $\begin{array}{c}\text { Annual income } \\
\text { (Rs) }\end{array}$ \\
\hline $\mathbf{1 .}$ & $<30$ & Illiterate & Marginal $(<1 \mathrm{ha})$ & $<1,00,000$ \\
\hline $\mathbf{2 .}$ & $30-40$ & Primary & Small $(1-2 \mathrm{ha})$ & $1-2,00,000$ \\
\hline $\mathbf{3 .}$ & $41-50$ & Middle school & Medium $(2.1-4 \mathrm{ha})$ & -- \\
\hline $\mathbf{4 .}$ & $>50$ & Secondary school & -- & -- \\
\hline $\mathbf{5}$ & -- & Higher secondary & -- & -- \\
\hline $\mathbf{6}$ & -- & Graduate & -- & -- \\
\hline
\end{tabular}


Table. 3 Cost and return in rice cultivation

\begin{tabular}{|r|l|c|c|}
\hline S. No & \multicolumn{1}{|c|}{ Particulars } & $\begin{array}{c}\text { Conventional } \\
\text { (Rs.) }\end{array}$ & $\begin{array}{c}\text { Machine } \\
\text { Transplanted (Rs.) }\end{array}$ \\
\hline 1. & Yield (productivity) in quintal & 21 & 23 \\
\hline 2. & $\begin{array}{l}\text { Average Price received (per } \\
\text { quintal) }\end{array}$ & Rs. 1,583/- & Rs. 1,583/- \\
\hline 3. & Cost of Cultivation (Rs. per acre) & Rs. 23808/- & Rs.20,815/- \\
\hline 4. & $\begin{array}{l}\text { Cost of Production (Rs. per } \\
\text { quintal) }\end{array}$ & Rs.1134/- & Rs. 806/- \\
\hline 5. & Gross return (per acre) & Rs.33,243/- & Rs.36,409/- \\
\hline 6. & Net return (per acre) & Rs.9,435/- & Rs.15,594/- \\
\hline
\end{tabular}

Table.4 Merits of the mechanical transplanting reported by the farmers

\begin{tabular}{|c|l|c|c|}
\hline S. No & \multicolumn{1}{|c|}{ Merits of the mechanical transplanting } & Response & Percentage \\
\hline $\mathbf{1}$ & Mental agony of rice cultivation reduced significantly & 11 & 100.00 \\
\hline $\mathbf{2}$ & Number of productive tiller increased & 11 & 100.00 \\
\hline $\mathbf{3}$ & $\begin{array}{l}\text { Reduction in seed rate resulted in reduction of cost of } \\
\text { cultivation }\end{array}$ & 11 & 100.00 \\
\hline $\mathbf{4}$ & Labour scarcity addressed & 11 & 100.00 \\
\hline
\end{tabular}

Table.5 Demerits of the mechanical transplanting reported by the farmers

\begin{tabular}{|c|l|c|c|}
\hline S. No & \multicolumn{1}{|c|}{ Demerits of the mechanical transplanting } & Response & Percentage \\
\hline 1. & Cono weeder is not available during the season. & 11 & 63.63 \\
\hline 2. & Leveling implements not available & 4 & 36.36 \\
\hline
\end{tabular}

The reasons for adoption of mechanical transplanter was reported by the sample respondents among the reasons 100 per cent of the respondents reported that labour scarcity and 90.90 were reported significant yield increase in this method planting were the major reasons for adoption followed by perfect maintenance of spacing between plants and rows as per the recommended spacing resulted in good aeration and finally less pest and disease incidences (Manjunatha et al., 2009).

It could be inferred that 72.72 per cent of the respondents reported that they were 100 per cent satisfied with mechanical transplantation followed by 27.27 per cent of the respondents reported that their level of satisfaction was 50 to 75 per cent on mechanical transplantation since it may not be suitable method of planting during rainy season, because after mechanical transplanting field should be given extra care for first 20 days after mechanical transplantation by means of providing proper drainage facility and irrigation should be applied as and when disappearance of water from the field.

\section{Merits and Demerits of machine transplanting}

The findings on the merits of machine transplanting are given in Table 4 and 5, which showed that cent percentage of the 
beneficiaries stated that the machine transplanting has contributed to significantly reduced the mental agony in rice cultivation, increased the number of productive tiller, reduced seed rate resulted in reduction of cost of cultivation.

The demerits of the machine transplanting methods were also studied and the findings are presented in Table 5. It could be inferred from the table 63.63 per cent $\& 36.36$ per cent of the respondent were notified the non availability of cono weeder and laser leveler respectively.

In conclusion the majority of the beneficiaries were 41 years and above and Cent per cent of the beneficiaries were literates and most of them were secondary school. Majority of the beneficiaries farming experience ranged between 21 to 30 years. Beneficiaries were distributed in the descending order of medium, small and marginal farmer categories. Around 90 per cent of the beneficiaries were in the annual income around Rs. 1 lakh. Beneficiaries reported the significantly reduced the mental agony in rice cultivation, increased the number of productive tiller, reduced seed rate resulted in reduction of cost of cultivation.

\section{References}

Ehsanullah, Ijaz Iqbal, Ashfaq Ahmad and Shakeel Ahmad Randhawa. Effect of Direct Seeding and Transplanting Methods on the Yield and Quality of Fine Rice Basmati-370. 2000. International Journal Of Agriculture \& Biology.

Tripathi, S. K., Jena, H. K. and Panda, P. K. 2004, Self-propelled rice transplanter for economizing labour, Indian Fmg., 54: 23 - 25.

MANJUNATHA, B. G. MASTHANA REDDY, S. D. SHASHIDHAR AND V. R. JOSHI.2009. Studies on the performance of self-propelled rice transplanter and its effect on crop yield. Karnataka J. Agric. Sci., 22(2) :(385387) 2009.

\section{How to cite this article:}

Anand, G. and Amuthaselvi, G. 2021. Impact Study on Manual Paddy Transplanters in Trichy District. Int.J.Curr.Microbiol.App.Sci. 10(02): 2639-2643. doi: https://doi.org/10.20546/ijcmas.2021.1002.289 